\title{
High Concentration of Iopromide Induces Apoptosis and Autophagy in Human Embryonic Kidney Cells via Activating a ROS-dependent Cellular Stress Pathway
}

\author{
YUH-FENG TSAI ${ }^{1,2}$, JAI-SING YANG $^{3}$, FUU-JEN TSAI ${ }^{4,5}$, YIH-DIH CHENG $^{6,7}$, \\ YU-JEN CHIU ${ }^{8,9,10}$ and SHIH-CHANG TSAI ${ }^{11}$ \\ ${ }^{1}$ Department of Diagnostic Radiology, Shin-Kong Wu Ho-Su Memorial Hospital, Taipei, Taiwan, R.O.C.; \\ ${ }^{2}$ School of Medicine, Fu-Jen Catholic University, New Taipei, Taiwan, R.O.C.; \\ ${ }^{3}$ Department of Medical Research, China Medical University Hospital, \\ China Medical University, Taichung, Taiwan, R.O.C.; \\ ${ }^{4}$ School of Chinese Medicine, College of Chinese Medicine, China Medical University, Taichung, Taiwan, R.O.C.; \\ ${ }^{5}$ China Medical University Children's Hospital, China Medical University, Taichung, Taiwan, R.O.C.; \\ ${ }^{6}$ School of Pharmacy, China Medical University, Taichung, Taiwan, R.O.C.; \\ ${ }^{7}$ Department of Pharmacy, China Medical University Hospital, Taichung, Taiwan, R.O.C.; \\ ${ }^{8}$ Division of Plastic and Reconstructive Surgery, Department of Surgery, \\ Taipei Veterans General Hospital, Taipei, Taiwan, R.O.C.; \\ ${ }^{9}$ Department of Surgery, School of Medicine, National Yang Ming University, Taipei, Taiwan, R.O.C.; \\ ${ }^{10}$ Institute of Clinical Medicine, National Yang-Ming University, Taipei, Taiwan, R.O.C.; \\ ${ }^{11}$ Department of Biological Science and Technology, China Medical University, Taichung, Taiwan, R.O.C.
}

\begin{abstract}
Background/Aim: The use of iodinated contrast media may impair renal function. However, no report has addressed the nephrotoxicity of high doses of iodinated contrast media in normal kidney cells and its associated molecular mechanisms. Materials and Methods: Cell proliferation was assessed using the MTT assay. Cell death was evaluated through examining the morphological changes and TUNEL assay. Autophagy was detected through acridine orange staining and lysotracker staining. Reactive oxygen species production and AKT kinase activity were examined. Results: Iopromide induced cell death and triggered apoptosis and autophagy in HEK 293 cells. Cell viability
\end{abstract}

This article is freely accessible online.

Correspondence to: Yu-Jen Chiu, Division of Plastic and Reconstructive Surgery, Department of Surgery, Taipei Veterans General Hospital, Taipei, No. 201, Sec. 2, Shipai Rd., Beitou District, Taipei City 11217, Taiwan, R.O.C. Tel: +886 228712121, e-mail: chiou70202@gmail.com; Shih-Chang Tsai, Department of Biological Science and Technology, China Medical University, No. 100, Sec. 1, Jing-Mao Road, Taichung 406040, Taiwan, R.O.C. Tel: +886422053366 ext2518, e-mail: sctsai@mail.cmu.edu.tw

Key Words: Iopromide, human embryonic kidney 293 cells, apoptosis, autophagy, reactive oxygen species. was significantly restored in the presence of a pan-caspase inhibitor or a ROS scavenger, N-acetyl-L-cysteine. AKT kinase activity was found to be reduced in iopromide-treated HEK 293 cells. Conclusion: High concentrations of iopromide induce cell damage, apoptosis, and autophagy through down-regulating AKT and ROS-activated cellular stress pathways in HEK 293 cells.

Roentgen discovered X-rays at the end of $19^{\text {th }}$ century, which was followed by the introduction of iodine-containing contrast media (ICCM) at the beginning of the $20^{\text {th }}$ century that opened up a new field of research in medical science (14). Iodine-containing contrast agents are administrated into the human body through veins and used for radiological diagnostic examinations of the urinary system, heart, cerebrospinal system, and blood vessels in various parts of the body. ICCM enhances the contrast between normal tissue and lesions, provides information on the morphologic features of the lesions, and improves the sensitivity of the examination and the accuracy of diagnosis. The imaging enhancement effect of the contrast agent makes many tissues and cell lesions visible (5-8). The main pharmacological mechanism is that the iodine molecules in the iodinecontaining contrast agent absorb X-ray energy, which makes the iodine molecules exert a special X-ray shielding effect. Therefore, a white high-density image appears on the X-ray 
film, thereby providing blood-containing tissue enhancement in images $(3,5,9,10)$.

The iodine-containing contrast agents are classified according to chemical structure, osmolality, and injection site. Based on the chemical structure, iodine-containing contrast agents are divided into four types: ionic monomer structures, ionic dimer structures, non-ionic monomer structures, and non-ionic dimer structures. Based on osmolality, iodine-containing contrast agents are divided into three types: high osmolar contrast media (HOCM), low osmolar contrast media (LOCM), and iso-osmolar contrast media (IOCM). Based on the injection site, iodine-containing contrast agents are divided into two types: intravascular, and subarachnoid contrast media (1). Generally, non-ionic iodinecontaining contrast agents exhibit lower osmolality than ionic iodine-containing contrast agents. Additionally, nonionic iodine-containing contrast agents are less toxic and exert allergic effects $(11,12)$. Injecting ICCM into the subarachnoid space must exhibit low neurotoxicity and low osmolality $(13,14)$.

Adverse drug reactions (ADRs) of iodine-containing contrast agents include allergic and chemical reactions. The main symptoms of allergic reactions are fever, nausea, vomiting, dizziness, skin rash, itching, sneezing, and nasal congestion $(4,11,12)$. Papules, urticaria, chills, chest tightness, shock, cardiopulmonary arrest, and death may occur in case of severe allergic reactions $(8,11,12)$. Adverse reactions and fatality rates of intravascular nonionic ICCM are approximately 2 to 7 per thousand and 2 to 9 per million, respectively (15-23). Adverse chemical reactions mainly lead to contrast-induced nephropathy (CIN). CIN is the impairment of renal function and worsening of renal function after the administration of iodine-containing contrast agents. The pathological mechanism may include vasoconstriction, renal blood flow changes, or direct toxicity to renal tubular cells (15-27). In 2006, Lameire et al. pointed out that CIN exerts direct toxic effects on renal tubular cells or hypoxia in the renal medulla $(4,28)$. The main causes of renal medullary hypoxia include decreased blood flow, decreased oxygen transport, and increased oxygen consumption. These factors may be related to an increase in the osmotic pressure, viscosity, and induction of prostaglandin E2 by $\operatorname{ICCM}(4,28)$.

Previous studies have demonstrated that low or isoosmolar contrast media at concentrations above $75 \mathrm{mgI} / \mathrm{ml}$ (six times as high as the normal dose concentration) could inhibit cell proliferation and induce cell death in kidney cells (KRK52-E, LLC-PK1, HKCS, HK-2). The types of cell death include apoptosis and autophagy (29-35). However, the detailed mechanisms remain unclear. In the present study, we investigated the molecular mechanisms, including cell damage, apoptosis, and autophagy, induced by iopromide, which is a LOCM, in HEK 293 cells.

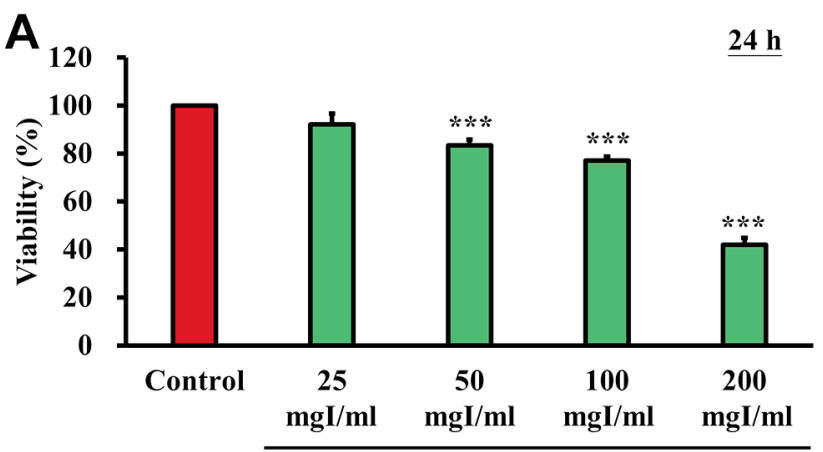

Iopromide

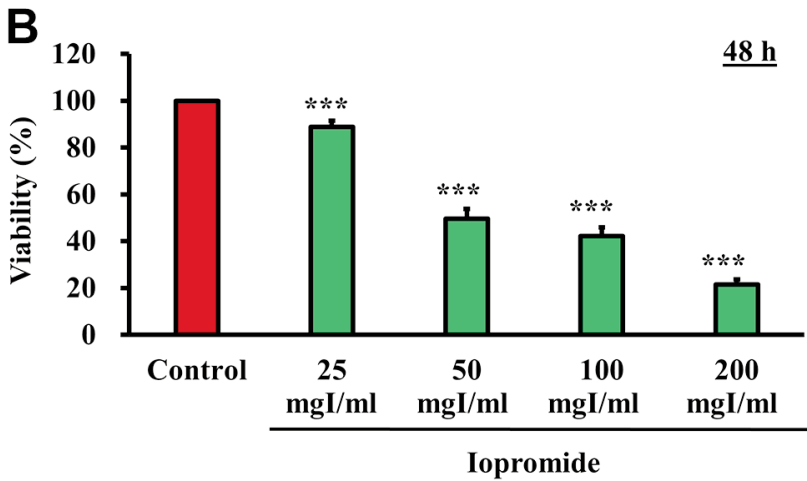

Figure 1. Iopromide inhibits HEK 293 cell proliferation. HEK 293 cells were seeded in 96 well plates for $24 \mathrm{~h}$ and subsequently incubated with $0,25,50,100$, and $200 \mathrm{mgI} / \mathrm{ml}$ iopromide for either $24 \mathrm{~h}$ (A) or $48 \mathrm{~h}$ (B). Cell viability of HEK 293 cells was evaluated using the MTT assay. The results are expressed relative to those of the untreated control and values are presented as mean $\pm S E(n=3)(* * * p<0.001)$.

\section{Materials and Methods}

Cell line and culture. The human embryonic kidney (HEK) 293 cell line was purchased from the Bioresource Collection and Research Center (Hsinchu, Taiwan, ROC). Cells were maintained in Dulbecco's modified Eagle's medium (DMEM) supplemented with $10 \%$ fetal bovine serum at $37^{\circ} \mathrm{C}$ in an incubator with $5 \% \mathrm{CO}_{2}$.

Reagents and chemicals. Iopromide (Ultravist ${ }^{\circledR}$ ) was obtained from Dr. Yuh-Feng Tsai of the Department of Diagnostic Radiology, Shin Kong Wu Ho Su Memorial Hospital. Except where indicated, the chemical reagents were purchased from Sigma-Aldrich (St. Louis, MO, USA).

Morphology and cell viability. HEK 293 cells $\left(0.8 \times 10^{4}\right.$ cells/well) were grown in 96 well plates for $24 \mathrm{~h}$ and treated with different concentrations $(0,25,50,100$, and $200 \mathrm{mgI} / \mathrm{ml})$ of iopromide for either 24 or $48 \mathrm{~h}$. Cell morphology was examined to assess apoptosis or autophagy using a light microscope at 200x magnification (Leica Microsystems GmbH, Wetzlar, Germany). Cell viability was assessed using the MTT assay (thiazolyl blue tetrazolium bromide) as described previously (36). Briefly, the cells were mixed with MTT for $4 \mathrm{~h}$. The absorbance at $570 \mathrm{~nm}$ was measured using a SpectraMax iD3 multimode microplate reader (Molecular Devices Ltd., San Jose, CA, USA). The percentage of 
A

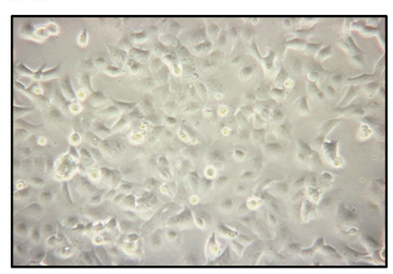

Control

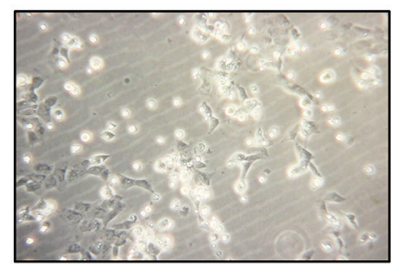

Iopromide (50 $\mathrm{mgI} / \mathrm{ml})$

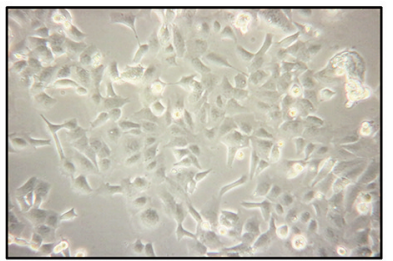

Iopromide (25 mgI/ml)

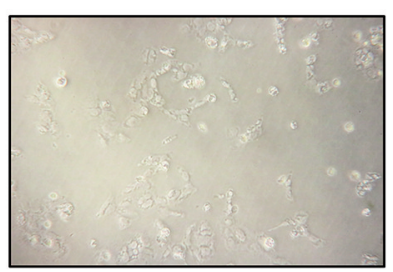

Iopromide (100 mgI/ml)
B

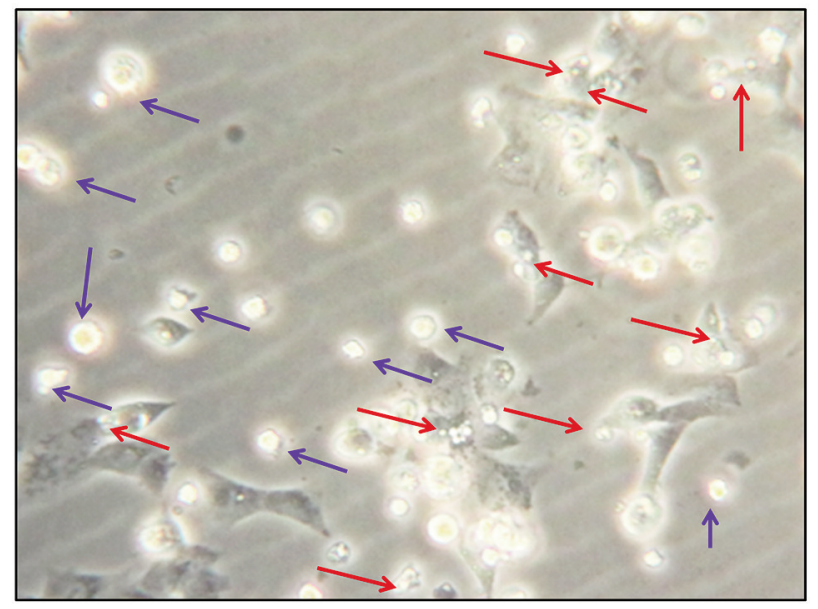

Iopromide (50 $\mathrm{mgI} / \mathrm{ml})$

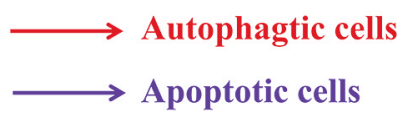

Figure 2. Changes in the morphology of HEK 293 cells. (A) HEK 293 cells were treated with 0, 25, 50, and 100 mgI/ml iopromide for 48 h. Changes in morphology were observed under a light microscope at 200x magnification. (B) Representative image HEK 293 cells -treated with 50 mgI/ml iopromide. Red arrows indicate the presence of vacuoles in iopromide-treated HEK 293 cells, suggesting that these cells were undergoing autophagy. Blue arrows indicate cells that became round and bright, suggesting that these cells were undergoing apoptosis.

cell viability was calculated through setting the untreated control group to $100 \%$.

Terminal deoxynucleotidyl transferase dUTP nick-end labeling (TUNEL) assay. To detect DNA breaks, an In Situ Cell Death Detection Kit (Roche, Mannheim, Germany) was used according to the manufacturer's instructions. Briefly, HEK 293 cells were seeded for $24 \mathrm{~h}$ followed by treatment with $50 \mathrm{mgI} / \mathrm{ml}$ iopromide for another $48 \mathrm{~h}$. Cells were fixed and stained with fluorescein probes. TUNEL-positive cells were analyzed using a NucleoCounter ${ }^{\circledR}$ NC3000 advanced image cytometer (ChemoMetec A/S, Allerod, Denmark). The relative fluorescence intensity was calculated using the ratio of the average mean of the sample fluorescence intensity to that of the untreated control cells. The relative fluorescence intensity is expressed as fold-change (37).

Caspase 3/7 and caspase 9 activity assays. To determine the alterations in caspase enzymatic activity, FAM FLICA ${ }^{\circledR}$ Caspases3/7 Assay Kit and FAM FLICA ${ }^{\circledR}$ Caspases-9 Assay Kit (MyBioSource, San Diego, CA, USA) were used according to the manufacturer's instructions. Briefly, HEK 293 cells were seeded into 6-well plates at a density of $1 \times 10^{6}$ cells/well for $24 \mathrm{~h}$ and treated with iopromide $(50 \mathrm{mgI} / \mathrm{ml}$ or $100 \mathrm{mgI} / \mathrm{ml})$ for another 48 h. Samples were assessed as described previously $(36,37)$ and analyzed using the NucleoCounter ${ }^{\circledR} \mathrm{NC}-3000^{\mathrm{TM}}$ advanced image cytometer (ChemoMetec A/S).

Acridine orange $(A O)$ staining. $\mathrm{AO}$ was used to examine whether acidic vesicular organelles (AVOs) were formed in iopromide- treated cells. Briefly, HEK 293 cells were seeded for $24 \mathrm{~h}$ followed by iopromide $(50 \mathrm{mgI} / \mathrm{ml})$ treatment for another $48 \mathrm{~h}$. Samples were prepared as described previously $(37,38)$. Red fluorescence intensity was measured and analyzed using a NucleoCounter ${ }^{\circledR}$ NC3000 advanced image cytometer (ChemoMetec A/S). The fluoresced bright red color represents the formation of acidic autophagic vacuoles. The relative fluorescence intensity was calculated using the ratio of the average mean of the sample fluorescence intensity to that of the untreated control cells. The relative fluorescence intensity is expressed as fold change.

LysoTracker red staining. HEK 293 cells were treated with 50 $\mathrm{mgI} / \mathrm{ml}$ iopromide for $48 \mathrm{~h}$, and samples were prepared as described previously $(37,38)$. Fluorescence intensity was measured and analyzed using a NucleoCounter ${ }^{\circledR}$ NC-3000 advanced image cytometer (ChemoMetec A/S). Fluorescent bright red represents the acidic organelles in cells. The relative fluorescence intensity was calculated using the ratio of the average mean of the sample fluorescence intensity to that of the untreated control cells. The relative fluorescence intensity is expressed as fold change.

Detection of reactive oxygen species (ROS) production. To detect the impact of iopromide on ROS production, HEK 293 cells were treated with $50 \mathrm{mgI} / \mathrm{ml}$ iopromide for $24 \mathrm{~h}$. Samples were prepared as described previously $(37,38)$. Briefly, $50 \mu \mathrm{M} \mathrm{CM}-\mathrm{H}_{2}$ DCFDA (General Oxidative Stress Indicator) (Abcam, Cambridge, UK) were added and cells were incubated for $30 \mathrm{~min}$ at $37^{\circ} \mathrm{C}$. The fluorescence intensity of the cells was measured using a NucleoCounter ${ }^{\circledR} \mathrm{NC}$ $3000^{\mathrm{TM}}$ advanced image cytometer (ChemoMetec $\mathrm{A} / \mathrm{S}$ ). 

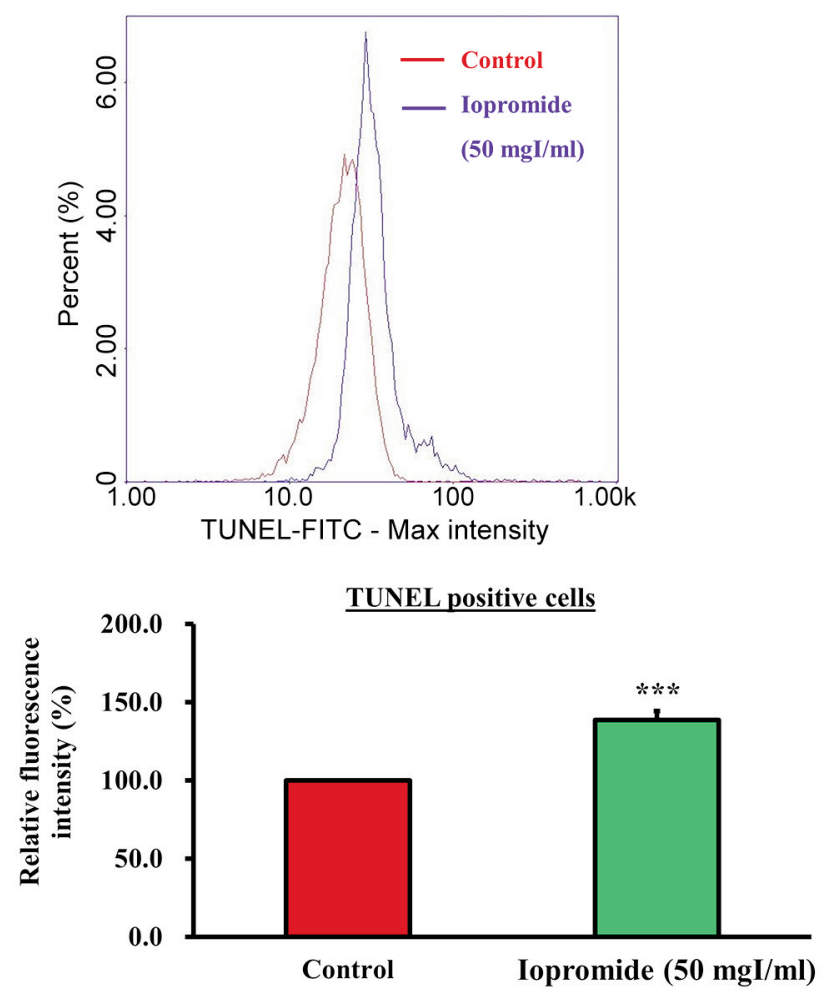

Figure 3. Iopromide induces DNA fragmentation and apoptosis. (A) HEK 293 cells were incubated with $50 \mathrm{mgI} / \mathrm{ml}$ iopromide for $48 \mathrm{~h}$. DNA breaks were determined using the TUNEL assay. TUNEL-positive cells were analyzed using the NucleoCounter ${ }^{\circledR} N C-3000^{T M}$ advanced image cytometer. (B) The relative fluorescence intensity was calculated using the ratio of the average mean of sample fluorescence intensity of iporomide-treated cells to that of untreated control cells. The relative fluorescence intensity is expressed as fold change. The results are expressed relative to those of the untreated control and values are presented as mean $\pm S E(n=3)(* * * p<0.001)$.

In vitro AKT kinase activity assay. To determine the alterations in the AKT kinase activity, an AKT Kinase Assay Kit (Cell Signaling Technology, Beverly, MA, USA) was used according to the manufacturer's instructions. HEK 293 cells $\left(2 \times 10^{6}\right.$ cells/dish $)$ were seeded in $10 \mathrm{~cm}$ dishes for $24 \mathrm{~h}$ and treated with either 50 or $100 \mathrm{mgI} / \mathrm{ml}$ iopromide for $24 \mathrm{~h}$. Cells were harvested and handled as described previously (39). Briefly, $200 \mathrm{mg}$ of protein from each sample was immunoprecipitated with $2 \mathrm{mg}$ of anti-AKT antibody overnight. AKT immunoprecipitates were mixed with glycogen synthase kinase- $3 \alpha / \beta$ substrate for $30 \mathrm{~min}$ at $30^{\circ} \mathrm{C}$. Samples were applied to $10 \%$ SDS-PAGE, and the relative intensity of phospho-GSK-3 $\alpha / \beta$ (Ser219) was determined compared to the untreated control.

Statistical analysis. Data were obtained from at least three independent experiments and expressed as mean \pm standard deviation (SD). Statistical differences were evaluated using the Student's $t$ test compared with the untreated control group. $p$ value less than 0.05 was considered statistically significant (37).

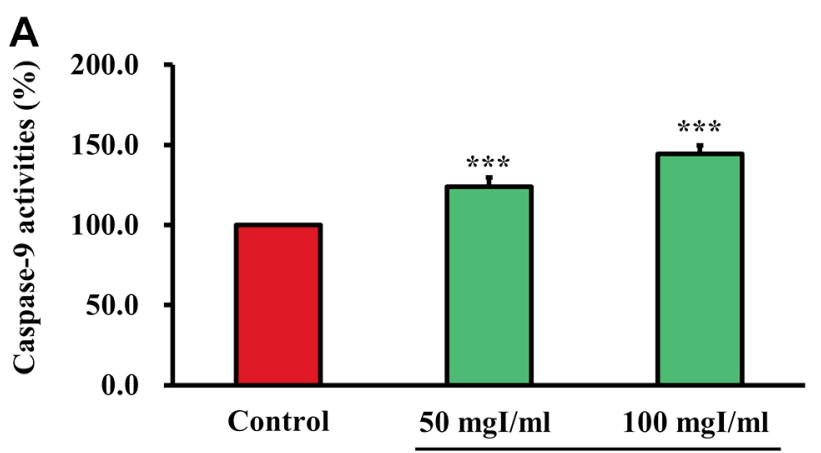

B

Iopromide

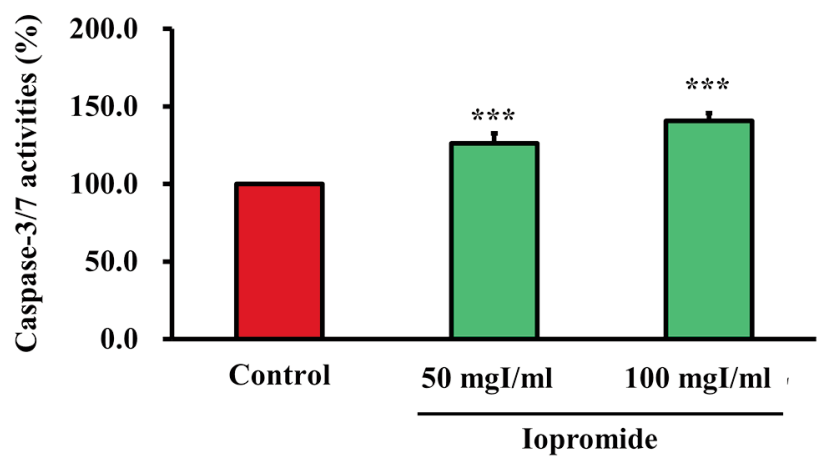

Figure 4. Iopromide activates caspase-9 and caspase-3/7 enzyme activities. HEK 293 cells were incubated with 50 or $100 \mathrm{mgI} / \mathrm{ml}$ iopromide for 48 h. (A) Caspase-9 and (B) Caspase-3/7 enzyme activities were measured. The results are expressed relative to those of the untreated control and values are presented as mean $\pm S E(n=3)$ $(* * * p<0.001)$.

\section{Results}

Iopromide significantly inhibited HEK 293 cell proliferation. To investigate the effect of iopromide on cell proliferation, HEK 293 cells were treated with $0,25,50,100$, and $200 \mathrm{mgI} / \mathrm{ml}$ iopromide for either 24 (Figure 1A) or $48 \mathrm{~h}$ (Figure 1B). Cell viability was measured using the MTT assay. The half-maximal inhibitory concentrations $\left(\mathrm{IC}_{50}\right)$ were $187 \pm 3.45 \mathrm{mgI} / \mathrm{ml}$ and $53.10 \pm 1.87 \mathrm{mgI} / \mathrm{ml}$ at 24 and $48 \mathrm{~h}$ of iopromide treatment, respectively (Figure 1). Our results revealed that iopromide inhibits cell proliferation. Additionally, morphological alterations in HEK 293 cells were observed when cells were treated with iopromide at concentrations higher than $50 \mathrm{mgI} / \mathrm{ml}$ for $48 \mathrm{~h}$ (Figure 2A). Some cells shrank and attained round shape, indicating that the cells might have undergone apoptosis. Meanwhile, some cells displayed vacuoles, which implied that the cells may have undergone autophagy (Figure 2B). 


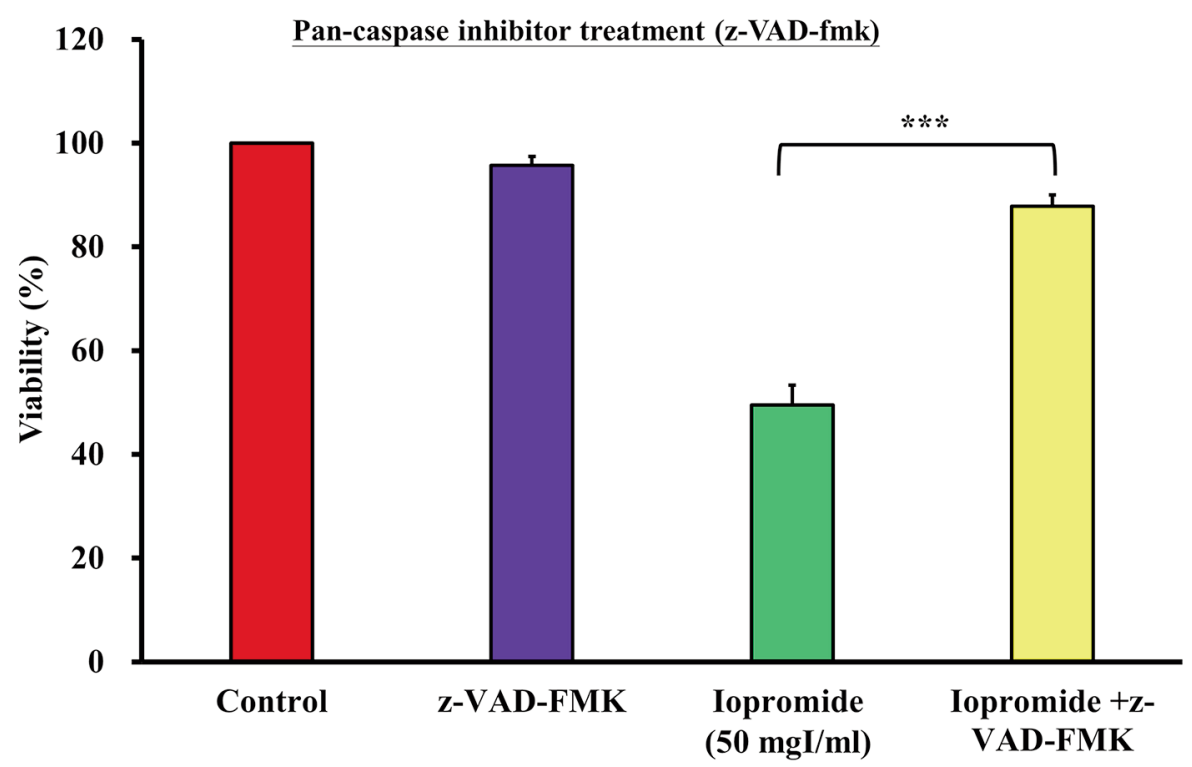

Figure 5. The pan-caspase inhibitor alleviates iopromide-induced cell death. HEK 293 cells were incubated with $50 \mathrm{mgI} / \mathrm{ml}$ iopromide in the absence or presence of the pan-caspase inhibitor (Z-VAD-FMK) for $48 \mathrm{~h}$. Cell viability was evaluated using the MTT assay. The results are expressed relative to those of the untreated control and values are presented as mean $\pm S E(n=3)(* * *<<0.001)$.

Iopromide induces cell death. To investigate whether iopromide induced cell death, we detected DNA breaks in iopromide-treated HEK 293 cells using the TUNEL assay. The relative TUNEL fluorescence intensity increased in iopromide-treated HEK 293 cells, thereby suggesting the presence of a large number of apoptotic cells (Figure 3A and B). Caspases are crucial mediators of apoptosis. During apoptosis, caspases are activated and initiate a cascade of catalytic activities. Caspase enzymatic activities were determined in HEK 293 cells treated with 50 or $100 \mathrm{mgI} / \mathrm{ml}$ iopromide for $48 \mathrm{~h}$ using the caspase assay kits. Caspase- 9 and Caspase-3/7 enzyme activities were elevated (Figure 4A and $\mathrm{B}$ ), thereby indicating that iopromide induced cell death. Furthermore, the pan-caspase inhibitor (Z-VAD-FMK) blocked death of iopromide-treated HEK 293 cells (Figure 5 ). These data revealed that iopromide induces apoptosis.

Iopromide triggers autophagy to protect cells from apoptosis. Autophagy acts as a "double-edged sword" and destroys damaged or aging organelles in response to external stressors, including oxidative stress or accumulation of protein aggregates. Recently, autophagy has also been shown to be involved in stress-induced cell death. To address the role of autophagy in iopromide-induced death of HEK 293 cells, we examined the formation of autophagic vesicles using AO and LysoTracker Red staining assays. Autophagic vacuoles were observed in HEK 293 cells treated with $50 \mathrm{mgI} / \mathrm{ml}$ iopromide (Figure 6A). Iopromide $(50 \mathrm{mgI} / \mathrm{ml})$ increased fluorescence intensity of acidic vesicular organelles (AVOs) and decreased
AO fluorescence intensity in HEK 293 cells (Figure 6B and C). Additionally, LysoTracker Red was used to identify acidic subcellular compartments in living cells. The number of acidic lysosomes and fluorescence intensity increased in iopromide-treated cells (Figure 7). The data indicated that autophagy occurred in iopromide-treated cells.

To clarify the relationship between autophagy and apoptosis, HEK 293 cells were pre-treated with the autophagy inhibitors 3-Methyladenine (3-MA) or bafilomycin A1 (Baf). Cells were subsequently treated with iopromide $(50 \mathrm{mg} / \mathrm{ml})$ for another $48 \mathrm{~h}$. Cell viability was assessed using the MTT assay. Cell viability further decreased to $30 \%$ upon treatment with iopromide and 3-Ma versus $53 \%$ in the iopromide only treatment group (Figure $8 \mathrm{~A})$. Meanwhile, cell viability further decreased to $18 \%$ upon treatment with iopromide and Baf versus $53 \%$ in the iopromide only treatment group (Figure $8 \mathrm{~B}$ ). These results suggested that iopromide-induced HEK 293 apoptosis is mediated through the induction of autophagy

Iopromide elicited ROS production and suppressed the AKT signaling pathway. A previous study demonstrated that ROS production was induced by iodinated contrast media (40). Indeed, treatment of HEK 293 cells with $50 \mathrm{mgI} / \mathrm{ml}$ iopromide resulted in a $165 \%$ increase in ROS production (Figure 9A and B). N-acetyl-L-cysteine (NAC), a ROS scavenger, blocked ROS production and restored cell growth (Figure 9C). ROS production is related to oxidative stress, which leads to the inactivation of AKT signaling pathway 
A

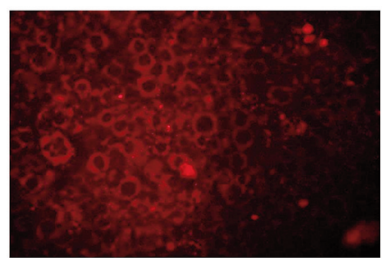

Control

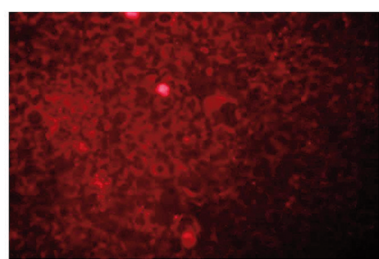

Iopromide (50 $\mathrm{mgI} / \mathrm{ml})$
B

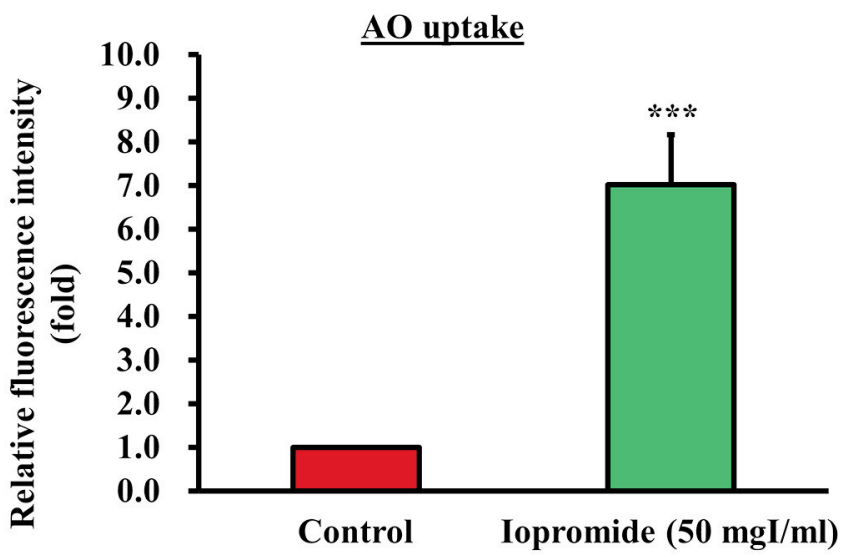

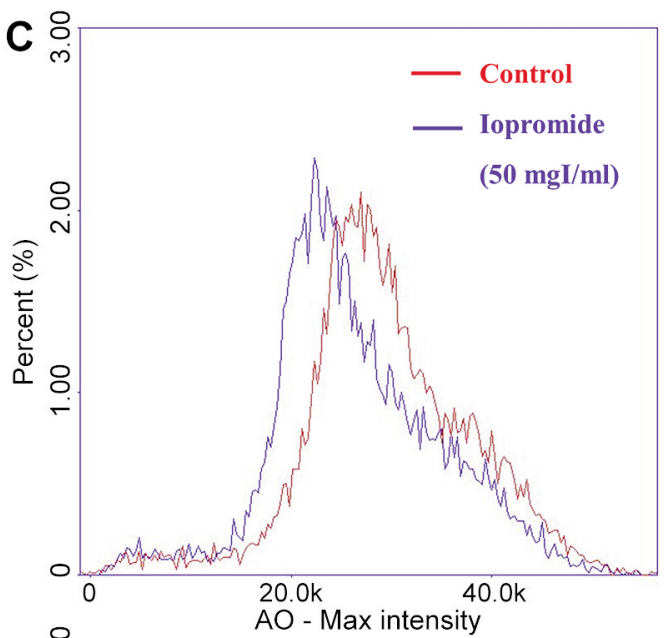

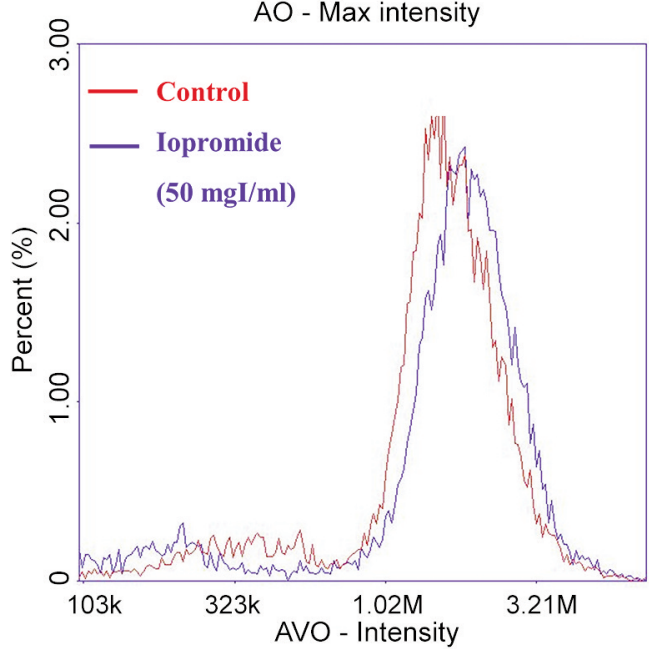

Figure 6. Iopromide induces the formation of acidic vacuoles in the autophagosomes. HEK 293 cells were incubated with 50 mgI/ml iopromide for $48 \mathrm{~h}$. The cells were stained with acridine orange (AO). (A) Representative fluorescent images of AO-stained cells. (B) The relative fluorescence intensity is expressed relative to that of the untreated control. (C) Representative histograms AO-and acidic vesicular organelles (AVOs)-stained cells generated using the image cytometer analysis. The results are expressed relative to those of the untreated control and values are presented as mean \pm SE (n=3) $(* * * p<0.001)$.

and induction of apoptosis (37). To examine whether AKT kinase activity is suppressed in iopromide $(50 \mathrm{mgI} / \mathrm{ml})$ treated HEK 293 cells, we measured AKT kinase activity. The AKT kinase activity was found to be reduced in iopromide-treated cells, which implied that AKT signaling was blocked (Figure 10A).

\section{Discussion}

Intravascular application of low osmolarity contrast media (LOCM) or iso-osmolar contrast media (IOCM) causes severe nephropathy and renal injury $(2,41,42)$. LOCM have also been known to induce allergic reactions. The frequency of adverse drug reactions (ADR), severe allergic reaction of lethality to LOCM is $0.2-0.7 \%, 1$ to $4 / 100,000$ and 2 $9 / 1000,000$, respectively (43). In our previous review, we showed that IOCM induces nephropathy and renal injury through increasing oxidative stress, enhancing renal vasoconstriction, and inducing tubular cell damage (43). Renal ischemia in the medulla, ROS production, reduction of nitric oxide production, and induction of tubular epithelial and vascular endothelial injury are risk factors for injury in cells and tissues $(44,45)$. In the present study, we investigated the cytotoxic effects of iopromide on apoptosis and autophagy in normal HEK 293 cells. Our results demonstrated that iopromide significantly increases apoptosis and autophagy in HEK 293 cells through the induction of a ROS-dependent pathway.

When a cell receives damaging extracellular stimuli, apoptosis or autophagy is induced as a rapid active response to injury. Many studies have suggested that iodinated contrast media (ICM) exerts cytotoxic effects and renal 
A

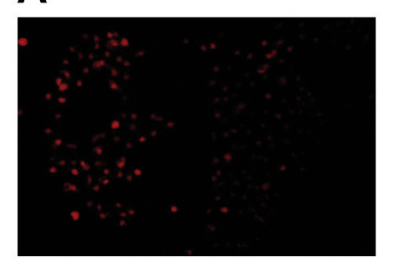

Control

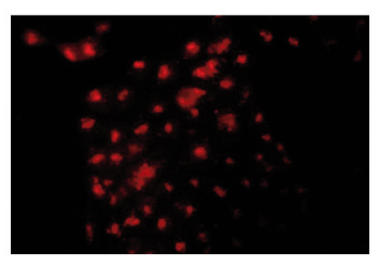

Iopromide (50 mgI/ml)
B

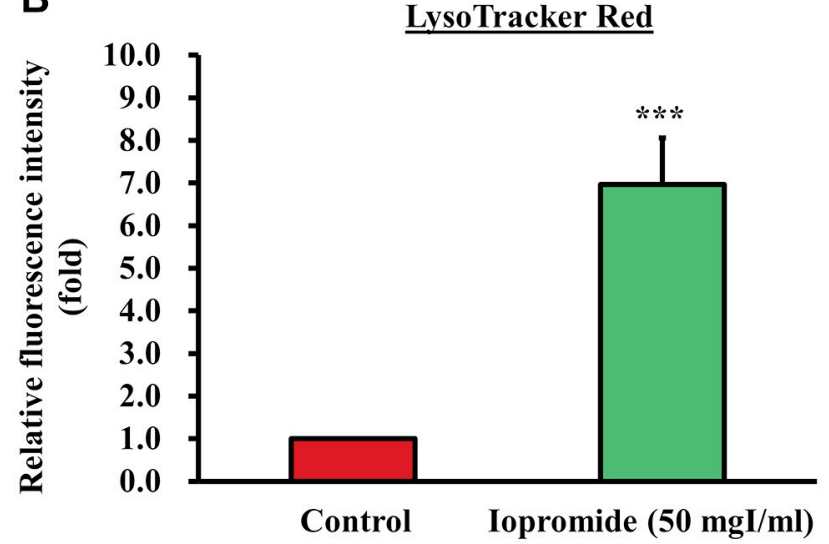

Figure 7. Iopromide increased lysosomal membrane permeability. HEK 293 cells were incubated with $50 \mathrm{mgI} / \mathrm{ml}$ iopromide for $48 \mathrm{~h}$. The cells were stained using LysoTracker Red. (A) Representative fluorescent images of LysoTracker Red-stained cells. (B) The fluorescence intensity is expressed relative to that of the untreated control and values are presented as mean $\pm S E(n=3)(* * * p<0.001)$.

tubular epithelial cell death via autophagy and/or apoptosis (46-49). Peer et al. demonstrated that iopromide, ioxaglate, and ioxatalamate induce apoptosis in renal mesangial, tubular, epithelial, endothelial, and hepatic cells (50). Tan et al. demonstrated that in NRK-52E cells, cell viability was decreased to $70 \%$ upon treatment with $150 \mathrm{mgI} / \mathrm{ml}$ iopromide compared to the control group (51). Ludwig et al. demonstrated that $120 \mathrm{mgI} / \mathrm{ml}$ iopromide treatment for $2 \mathrm{~h}$ induced DNA fragmentation in human proximal renal tubular (HK-2) cells (52). Our results demonstrated that iopromide reduced HEK 293 cell viability in a time- and concentrationdependent manner (Figure 1). Iopromide induced morphological alterations, DNA fragmentation, apoptosis and autophagy in HEK 293 cells (Figure 2). Iopromide induced caspase-3/-7 and caspase-9 activities at concentrations 50 and $100 \mathrm{mgI} / \mathrm{ml}$ in HEK 293 cells (Figure 4A and B). Additionally, the cell viability results revealed that iopromide-induced cytotoxicity in HEK 293 cells was significantly inhibited by the addition of pan-caspase inhibitor (Figure 5). These results indicated that iopromide induces DNA damage and apoptotic cell death mediated caspase 9 and caspase 3/-7 activities.
Recently, Lei Rong et. al. suggested that autophagy plays a protective role in iohexol- and iodixanol-induced injury in human renal tubular epithelial HK-2 cells (47). However, it remained unclear whether autophagy is associated with iopromide-induced normal HEK 293 cell injury. To examine the effect of iopromide on autophagy we used the AO staining assay. AO is a lysosomotropic green fluorescent probe that gets protonated and trapped inside acidic vesicular organelles (AVOs). Autophagy is characterized by an increase in the formation of AVOs. Therefore, AVOs can be quantified through imaging or flow cytometry after staining the cells with AO $(41,53-55)$. As shown in Figure 6A and $\mathrm{B}$, iopromide increased fluorescence intensity AVOs and decreased cellular AO fluorescence intensity (Figure 6C) in HEK 293 cells. Our results indicated that iopromide induced autophagy, as assessed using AO staining assay. We also demonstrated that iopromide increased the fluorescence intensity of LysoTracker Red, thereby suggesting that iopromide induced lysosome activity during the autophagy process (Figure 7). Previous studies have demonstrated that autophagy plays a protective role in cisplatin-induced renal tubular epithelial cell injury (56-58). To further examine the role of autophagy in iopromide-induced cell death, HEK 293 cells were treated with the autophagy inhibitors 3methyladenine (3-MA) or bafilomycin A1 (Baf). Combination treatment (iopromide with 3-MA or Baf) significantly decreased cell viability when compared with iopromide alone (Figure 8), suggesting that autophagy plays a protective role in iopromide-induced HEK 293 cell injury.

ICM enters the cells and induces changes in mitochondrial function, thereby resulting in increased ROS generation and apoptotic cell death (59). Tana Xuexian et al. also demonstrated a significant increase in ROS production in iopromide-treated NRK-52E cells (60). Antioxidant agents, including sodium bicarbonate, NAC, ascorbic acid (Vitamin C), statins, and phosphodiesterase type 5 inhibitors have been demonstrated to ICM-induced effects (61-65). In an in vivo study, NAC was shown to be more effective than hyperhydration alone in preventing contrast-induced acute renal failure (63). In the present study, we demonstrated that iopromide induced ROS production in HEK 293 cells (Figure 9A and B). Cell viability was found to be significantly increased in the iopromide plus NAC group compared to the iopromide only group (Figure 9C).

Alterations in AKT activity are essential for cell survival and have been shown to strongly regulate apoptosis and autophagy in the presence of ICM (66-68). Here, we investigated the effect of iopromide on the regulation of AKT in HEK 293 cells. The results revealed a marked reduction in the AKT kinase activity in iopromide-treated cells compared to the control cells. Our results suggest that the inhibition of AKT activity is correlated with iopromideinduced apoptosis and autophagy, which may be controlled 

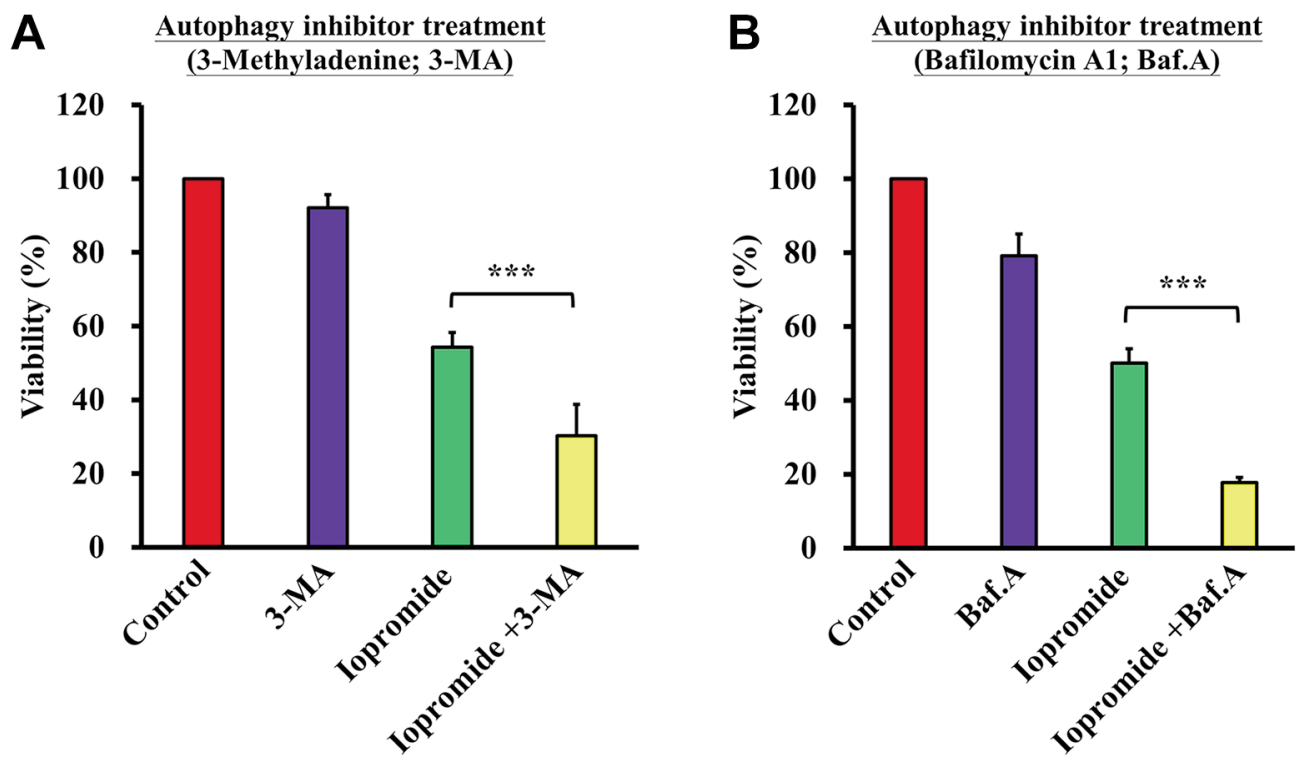

Figure 8. Autophagy inhibitors enhance cell death in iopromide-treated cells. HEK 293 cells were pretreated with (A) 1 mM 3-methyladenine (3$M A)$ and (B) $100 \mathrm{nM}$ bafilomycin Al (Baf) for $4 \mathrm{~h}$, and then incubated with $50 \mathrm{mgI} / \mathrm{ml}$ iopromide for $48 \mathrm{~h}$. Cell viability was assessed using the MTT assay. The results are expressed relative to those of the untreated control and values are presented as mean $\pm S E(n=3)(* * * p<0.001)$.
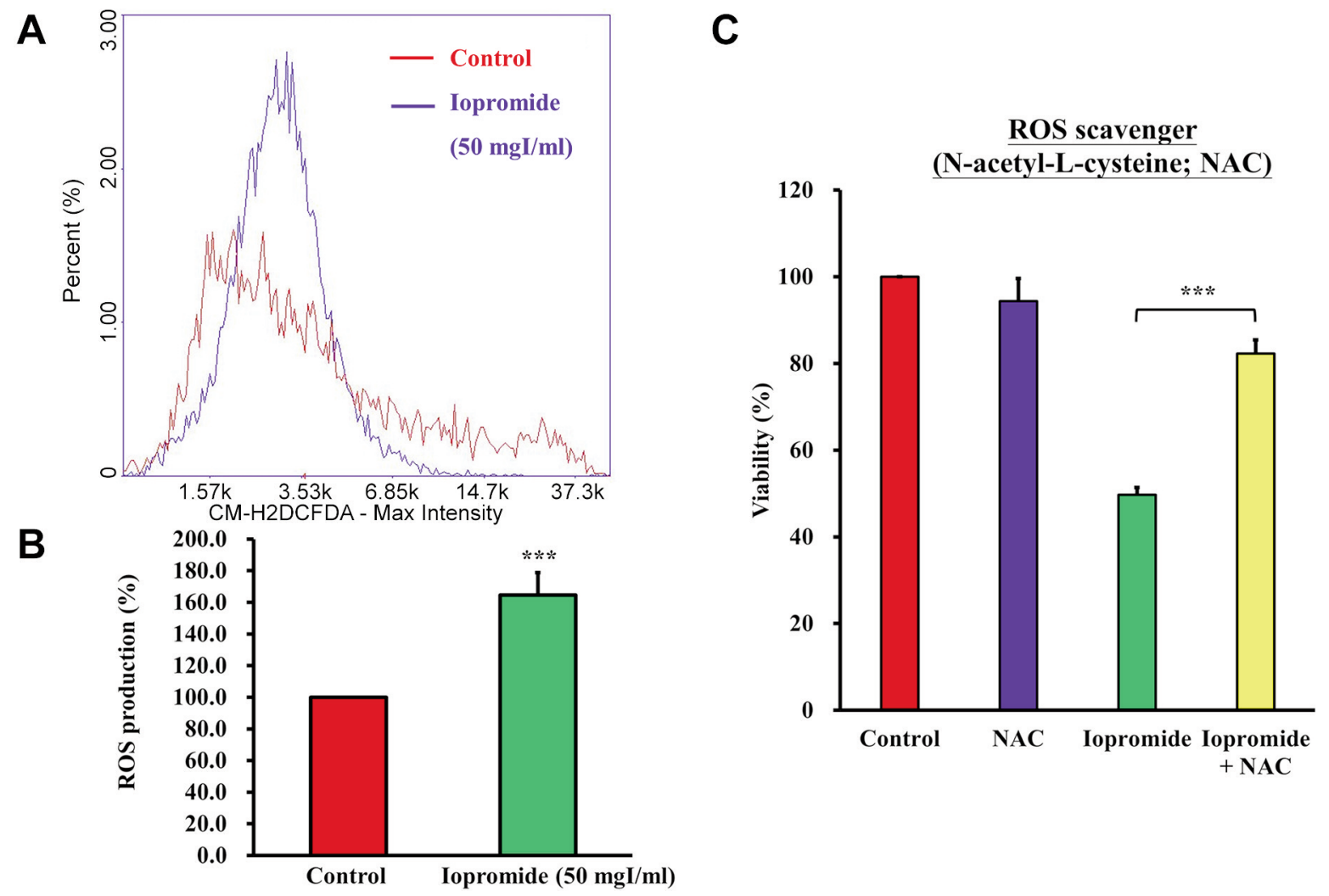

Figure 9. Iopromide elicits reactive oxygen species (ROS) production. HEK 293 cells were incubated with $50 \mathrm{mgI} / \mathrm{ml}$ iopromide for 24 h. The cells were stained with $50 \mu M C M-H_{2} D C F D A$ (General Oxidative Stress Indicator). (A) Representative cytometer histogram of CM- $H_{2} D C F D A$ stained cells. (B) The percentage of ROS production in treated samples was compared with that of the untreated control. (C) The ROS scavenger (N-acetylL-cysteine; NAC) was added in iopromide-treated cells. Cell viability was evaluated using the MTT assay. The results are expressed relative to those of the untreated control and values are presented as mean $\pm S E(n=3)(* * * p<0.001)$. 
A

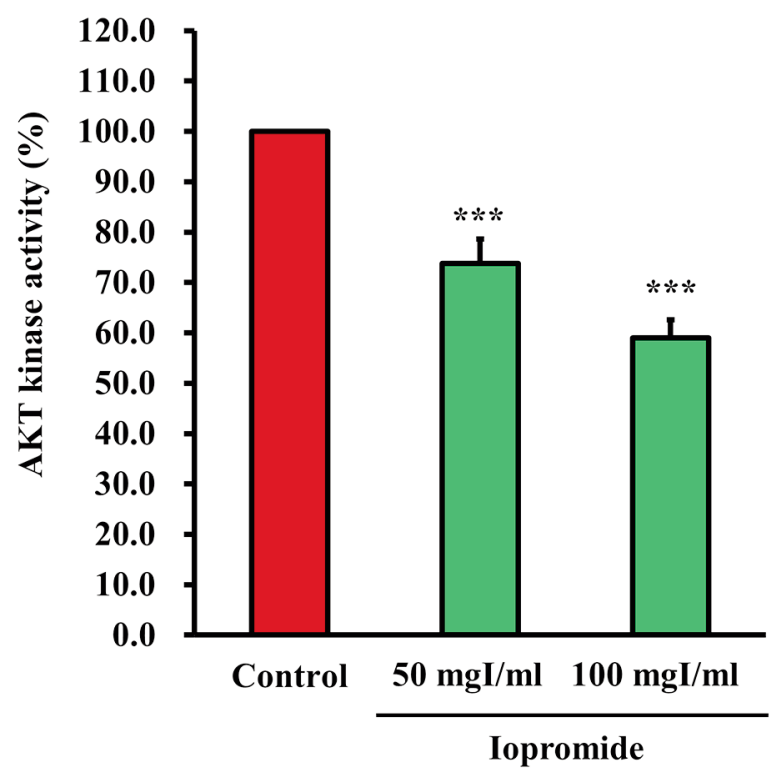

B

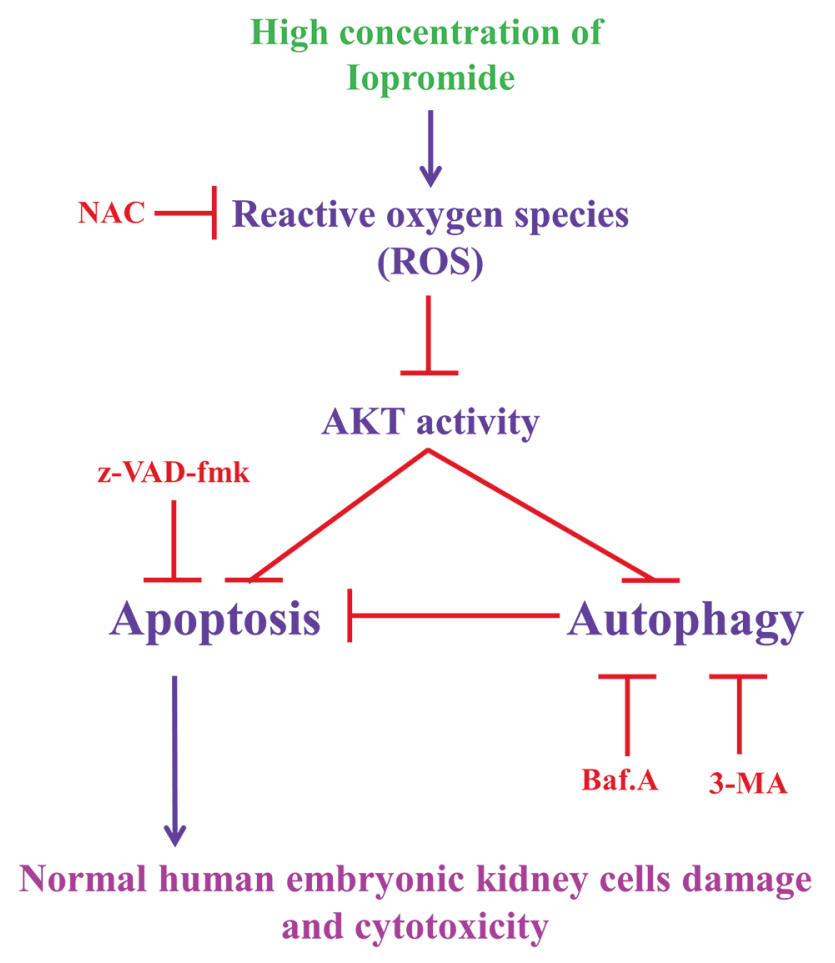

Figure 10. Iopromide inhibits the AKT kinase activity. (A) HEK 293 cells were incubated with $50 \mathrm{mgI} / \mathrm{ml}$ iopromide for 24 h. Samples were assayed for AKT kinase activity. The results are expressed relative to those of the untreated control and values are presented as mean $\pm S E(n=3)(* * * p<0.001)$. (B) A working model depicting the underlying mechanism of action of iopromide.

through the AKT signaling pathway. Our results suggest that iopromide induces ROS production, which inhibit AKT kinase activity and signaling. The AKT signaling pathway positively correlates with cell survival and negatively associates with cell death and autophagy.

In this study, we demonstrated that autophagy protected cells from apoptosis. Cell damage and cytotoxicity of HEK cells were initiated by iopromide-induced apoptosis (Figure 10B). Conclusively, we demonstrated that iopromide significantly inhibited HEK 293 cell viability and induced apoptosis and autophagy compared to the control group in vitro. Moreover, high concentrations of iopromide induce cell damage, apoptosis, and autophagy via ROS-dependent cellular stress and inhibition of AKT signaling pathway in normal HEK 293 cells.

\section{Funding}

The present study was supported by a grant awarded to Dr. Yuh-Feng Tsai of the Shin-Kong Wu Ho-Su Memorial Hospital, Taipei, Taiwan (grant no. 2018SKHADR026), in part through a grant grant awarded to Dr. Jai Sing Yang of China Medical University Hospital, Taichung, Taiwan (grant no. DMR-110-155), a grant awarded to Dr. Jai-Sing Yang of China Medical University Hospital, Taichung, Taiwan (grant no. DMR-110-155), a grant awarded to Dr. Yu-Jen Chiu of Taipei Veterans General Hospital, Taipei, Taiwan (grant no. V110B-038) and Yen Tjing Ling Medical Foundation, Taipei, Taiwan (CI-110-6).

\section{Conflicts of Interest}

All the Authors have declared no conflicts of interest in relation to this study.

\section{Authors' Contributions}

YFT, JSY, FJT, YDC, YJC, and SCT conceived and designed the experiments. JSY, YDC, and FJT performed the experiments. YFT, JSY, and YDC analyzed the data. JSY, YJC, and SCT wrote and revised the manuscript. All Authors read and approved the manuscript and agreed to be accountable for all aspects of the research to ensure that the accuracy or integrity of any part of the work are appropriately investigated and resolved.

\section{Acknowledgements}

The Authors would like to thank the staff at the Office of Research \& Development at China Medical University, Taichung, Taiwan, R.O.C., for using the Medical Research Core Facilities to perform experiments and data analysis. 


\section{References}

1 Yang JS, Peng YR, Tsai SC, Tyan YS, Lu CC, Chiu HY, Chiu YJ, Kuo SC, Tsai YF, Lin PC and Tsai FJ: The molecular mechanism of contrast-induced nephropathy (CIN) and its link to in vitro studies on iodinated contrast media (CM). Biomedicine (Taipei) 8(1): 1, 2018. PMID: 29480796. DOI: $10.1051 / \mathrm{bmdcn} / 2018080101$

2 Shams E and Mayrovitz HN: Contrast-induced nephropathy: a review of mechanisms and risks. Cureus 13(5): e14842, 2021. PMID: 34104587. DOI: 10.7759/cureus.14842

3 Mamoulakis C, Tsarouhas K, Fragkiadoulaki I, Heretis I, Wilks MF, Spandidos DA, Tsitsimpikou C and Tsatsakis A: Contrast-induced nephropathy: Basic concepts, pathophysiological implications and prevention strategies. Pharmacol Ther 180: 99-112, 2017. PMID: 28642116. DOI: 10.1016/j.pharmthera.2017.06.009

4 Bagshaw SM and Culleton BF: Contrast-induced nephropathy: epidemiology and prevention. Minerva Cardioangiol 54(1): 109129, 2006. PMID: 16467746.

5 La Grutta L, Toia P, Maffei E, Cademartiri F, Lagalla R and Midiri M: Infarct characterization using CT. Cardiovasc Diagn Ther 7(2): 171-188, 2017. PMID: 28540212. DOI: 10.21037/ cdt.2017.03.18

6 Rybicki FJ, Piazzo K, Prior R, Wake N and Dill KE: Iodinated contrast injection data from a new technology. Radiol Technol 84(2): 120-125, 2012. PMID: 23125373.

7 Meunier B, Joskin J, Damas F and Meunier P: [Iodinated contrast media and iodine allergy: myth or reality?]. Rev Med Liege 68(9): 465-469, 2013. PMID: 24180202.

8 Goodwill PW, Saritas EU, Croft LR, Kim TN, Krishnan KM, Schaffer DV and Conolly SM: X-space MPI: magnetic nanoparticles for safe medical imaging. Adv Mater 24(28): 38703877, 2012. PMID: 22988557. DOI: 10.1002/adma.201200221

9 Harbron R, Ainsbury EA, Bouffler SD, Tanner RJ, Eakins JS and Pearce MS: Enhanced radiation dose and DNA damage associated with iodinated contrast media in diagnostic X-ray imaging. Br J Radiol 90(1079): 20170028, 2017. PMID: 28830201. DOI: 10.1259/bjr.20170028

10 Prezzi D, Khan A and Goh V: Perfusion CT imaging of treatment response in oncology. Eur J Radiol 84(12): 2380-2385, 2015. PMID: 25864440. DOI: 10.1016/j.ejrad.2015.03.022

11 Costa N: Understanding contrast media. J Infus Nurs 27(5): 302312, 2004. PMID: 15385894. DOI: 10.1097/00129804-20040900000004

12 Bettmann MA and Morris TW: Recent advances in contrast agents. Radiol Clin North Am 24(3): 347-357, 1986. PMID: 3529226.

13 Pugh ND, Griffith TM and Karlsson JO: Effects of iodinated contrast media on peripheral blood flow. Acta Radiol Suppl 399: 155-163, 1995. PMID: 8610509. DOI: 10.1177/ $0284185195036 \mathrm{~s} 39918$

14 Stolberg HO and McClennan BL: Ionic versus nonionic contrast use. Curr Probl Diagn Radiol 20(2): 47-88, 1991. PMID: 2049958. DOI: 10.1016/0363-0188(91)90019-x

15 Modi K and Dulebohn SC: Contrast induced nephropathy. Statpearls, Treasure Island, FL, USA, 2017.

16 Ursta AA, Kharkov EI, Petrova MM, Ursta OV, Kotikov AR and Kiselev AN: [Contrast induced nephropathy in the older age group patients]. Adv Gerontol 30(2): 306-310, 2017. PMID: 28575573.
17 Wong GT, Lee EY and Irwin MG: Contrast induced nephropathy in vascular surgery. Br J Anaesth 117 Suppl 2: ii63-ii73, 2016. PMID: 27566809. DOI: 10.1093/bja/aew213

18 Davenport MS, Cohan RH and Ellis JH: Contrast media controversies in 2015: imaging patients with renal impairment or risk of contrast reaction. AJR Am J Roentgenol 204(6): 11741181, 2015. PMID: 25730301. DOI: 10.2214/AJR.14.14259

19 Homma K: Contrast-induced acute kidney injury. Keio J Med 65(4): 67-73, 2016. PMID: 27170234. DOI: 10.2302/kjm.20150013-IR

20 McCullough PA, Choi JP, Feghali GA, Schussler JM, Stoler RM, Vallabahn RC and Mehta A: Contrast-induced acute kidney injury. J Am Coll Cardiol 68(13): 1465-1473, 2016. PMID: 27659469. DOI: 10.1016/j.jacc.2016.05.099

21 Genovesi E, Romanello M and De Caterina R: [Contrast-induced acute kidney injury in cardiology]. G Ital Cardiol (Rome) 17(12): 984-1000, 2016. PMID: 28151503. DOI: 10.1714/ 2612.26891

22 Ozkok S and Ozkok A: Contrast-induced acute kidney injury: A review of practical points. World J Nephrol 6(3): 86-99, 2017. PMID: 28540198. DOI: 10.5527/wjn.v6.i3.86

23 Chalikias G, Drosos I and Tziakas DN: Contrast-induced acute kidney injury: an update. Cardiovasc Drugs Ther 30(2): 215-228, 2016. PMID: 26780748. DOI: 10.1007/s 10557-015-6635-0

24 Mohammed NM, Mahfouz A, Achkar K, Rafie IM and Hajar R: Contrast-induced nephropathy. Heart Views 14(3): 106-116, 2013. PMID: 24696755. DOI: 10.4103/1995-705X.125926

25 Wichmann JL, Katzberg RW, Litwin SE, Zwerner PL, De Cecco CN, Vog1 TJ, Costello P and Schoepf UJ: Contrast-induced nephropathy. Circulation 132(20): 1931-1936, 2015. PMID: 26572669. DOI: 10.1161/CIRCULATIONAHA.115.014672

26 John M. Eisenberg Center for Clinical Decisions and Communications Science: Contrast-induced nephropathy (cin): Current state of the evidence on contrast media and prevention of cin. In: Comparative effectiveness review summary guides for clinicians. Agency for Healthcare Research and Quality, Rockville, MD, USA, 2007.

27 Katsiki N, Athyros VG, Karagiannis A and Mikhailidis DP: Contrast-induced nephropathy: An "All or None" phenomenon? Angiology 66(6): 508-513, 2015. PMID: 25225196. DOI: $10.1177 / 0003319714550309$

28 Lameire NH: Contrast-induced nephropathy - prevention and risk reduction. Nephrol Dial Transplant 21(6): i11-i23, 2006. PMID: 16723348 . DOI: $10.1093 / \mathrm{ndt} / \mathrm{gfl} 215$

29 Heinrich MC, Scheer M, Heckmann M, Kuefner MA and Uder M: Iodixanol induces apoptotic and antiproliferative effects but no necrotic cell death in renal proximal tubular cells in vitro. Rofo 181(4): 349-354, 2009. PMID: 19291604. DOI: 10.1055/s0028-1109127

30 Yao L, Kolluru GK, Kevil CG and Zhang WW: Intravascular radiocontrast iodixanol increases permeability of proximal tubule epithelium: a possible mechanism of contrast-induced nephropathy. Vasc Endovascular Surg 47(8): 632-638, 2013. PMID: 24005192. DOI: 10.1177/1538574413503560

31 Lerch M, Keller M, Britschgi M, Kanny G, Tache V, Schmid DA, Beeler A, Gerber BO, Luethi M, Bircher AJ, Christiansen $\mathrm{C}$ and Pichler WJ: Cross-reactivity patterns of $\mathrm{T}$ cells specific for iodinated contrast media. J Allergy Clin Immunol 119(6): 1529-1536, 2007. PMID: 17412404. DOI: 10.1016/j.jaci.2007. 02.007 
32 Zager RA, Johnson AC and Hanson SY: Radiographic contrast media-induced tubular injury: evaluation of oxidant stress and plasma membrane integrity. Kidney Int 64(1): 128-139, 2003. PMID: 12787403. DOI: 10.1046/j.1523-1755.2003.00059.x

33 Yokomaku Y, Sugimoto T, Kume S, Araki S, Isshiki K, ChinKanasaki M, Sakaguchi M, Nitta N, Haneda M, Koya D, Uzu T and Kashiwagi A: Asialoerythropoietin prevents contrast-induced nephropathy. J Am Soc Nephrol 19(2): 321-328, 2008. PMID: 18184858. DOI: 10.1681/ASN.2007040481

34 Duan S, Zhou X, Liu F, Peng Y, Chen Y, Pei Y, Ling G, Zhou L, Li Y, Pi Y, Tang K, Liu R and Li G: Comparative cytotoxicity of high-osmolar and low-osmolar contrast media on HKCs in vitro. J Nephrol 19(6): 717-724, 2006. PMID: 17173243.

35 Heinrich M, Scheer M, Heckmann M, Bautz W and Uder M: Reversibility and time-dependency of contrast medium induced inhibition of 3-(4,5-dimethylthiazol-2-yl)-2,5-diphenyltetrazolium bromide (MTT) conversion in renal proximal tubular cells in vitro: comparison of a monomeric and a dimeric nonionic iodinated contrast medium. Invest Radiol 42(11): 732738, 2007. PMID: 18030195. DOI: 10.1097/RLI 0b013e3180ebe6a2

36 Tsai YF, Chen YF, Hsiao CY, Huang CW, Lu CC, Tsai SC and Yang JS: Caspase dependent apoptotic death by gadolinium chloride $(\mathrm{GdCl} 3)$ via reactive oxygen species production and MAPK signaling in rat C6 glioma cells. Oncol Rep 41(2): 13241332, 2019. PMID: 30535448. DOI: 10.3892/or.2018.6913

37 Ha HA, Chiang JH, Tsai FJ, Bau DT, Juan YN, Lo YH, Hour MJ and Yang JS: Novel quinazolinone MJ 33 induces AKT/mTOR mediated autophagy associated apoptosis in 5FU resistant colorectal cancer cells. Oncol Rep 45(2): 680-692, 2021. PMID: 33416156. DOI: 10.3892/or.2020.7882

38 Huang WW, Yang JS, Pai SJ, Wu PP, Chang SJ, Chueh FS, Fan MJ, Chiou SM, Kuo HM, Yeh CC, Chen PY, Tsuzuki M and Chung JG: Bufalin induces G0/G1 phase arrest through inhibiting the levels of cyclin D, cyclin E, CDK2 and CDK4, and triggers apoptosis via mitochondrial signaling pathway in T24 human bladder cancer cells. Mutat Res 732(1-2): 26-33 2012. PMID: 22285700. DOI: 10.1016/j.mrfmmm.2011.09.010

39 Chiu YJ, Hour MJ, Jin YA, Lu CC, Tsai FJ, Chen TL, Ma H, Juan YN and Yang JS: Disruption of IGF 1R signaling by a novel quinazoline derivative, HMJ 30, inhibits invasiveness and reverses epithelial-mesenchymal transition in osteosarcoma U 2 OS cells. Int J Oncol 52(5): 1465-1478, 2018. PMID: 29568964. DOI: $10.3892 /$ ijo.2018.4325

40 Li Y, Huang J, He S, Lu Z, Zhang J, Li X, Yang Z, Hoffman RM and $\mathrm{Wu} \mathrm{Q}:$ APELA/ELA32 reduces iodixanol-induced apoptosis, inflammatory response and mitochondrial and DNA damage in renal tubular epithelial cells. Anticancer Res 40(2): 635-643, 2020. PMID: 32014904. DOI: 10.21873/anticanres.13993

41 Boozari $\mathrm{M}$ and Hosseinzadeh H: Preventing contrast-induced nephropathy (CIN) with herbal medicines: A review. Phytother Res 35(3): 1130-1146, 2021. PMID: 33015894. DOI: 10.1002/ ptr.6880

42 Modi K, Padala SA and Gupta M: Contrast-induced nephropathy. Statpearls, Treasure Island, FL, USA, 2021.

43 Chang LC, Hsieh MT, Yang JS, Lu CC, Tsai FJ, Tsao JW, Chiu YJ, Kuo SC and Lee KH: Effect of bis(hydroxymethyl) alkanoate curcuminoid derivative MTH-3 on cell cycle arrest, apoptotic and autophagic pathway in triple-negative breast adenocarcinoma MDA-MB-231 cells: An in vitro study. Int J
Oncol 52(1): 67-76, 2018. PMID: 29138806. DOI: 10.3892/ijo. 2017.4204

44 Tao SM, Wichmann JL, Schoepf UJ, Fuller SR, Lu GM and Zhang LJ: Contrast-induced nephropathy in CT: incidence, risk factors and strategies for prevention. Eur Radiol 26(9): 33103318, 2016. PMID: 26685852. DOI: 10.1007/s00330-015-41558

45 Santos PR, Carneiro Neto JD, Arcanjo FP, Carneiro JK, Carneiro RC and do Amaral CL: Contrast-induced nephropathy after primary angioplasty for acute myocardial infarction. J Bras Nefrol 37(4): 439-445, 2015. PMID: 26648492. DOI: 10.5935/ 0101-2800.20150070

46 Jiang W, Zhao W, Ye F, Huang S, Wu Y, Chen H, Zhou R and Fu G: Inhibiting PKC $\beta 2$ protects $\mathrm{HK}-2$ cells against meglumine diatrizoate and AGEs-induced apoptosis and autophagy. Ann Transl Med 8(6): 293, 2020. PMID: 32355737. DOI: 10.21037/atm.2020.02.172

47 Lan J, Huang L, Lou H, Chen C, Liu T, Hu S, Yao Y, Song J, Luo J, Liu Y, Xia B, Xia L, Zeng X, Ben-David Y and Pan W: Design and synthesis of novel $\mathrm{C}_{14}$-urea-tetrandrine derivatives with potent anti-cancer activity. Eur J Med Chem 143: 19681980, 2018. PMID: 29133049. DOI: 10.1016/j.ejmech. 2017.11.007

48 Buyuklu M, Kandemir FM, Ozkaraca M, Set T, Bakirci EM, Topal E, Ileriturk $\mathrm{M}$ and Turkmen $\mathrm{K}$ : Benefical effects of lycopene against contrast medium-induced oxidative stress, inflammation, autophagy, and apoptosis in rat kidney. Hum Exp Toxicol 34(5): 487-496, 2015. PMID: 25205736. DOI: 10.1177/ 0960327114542964

49 Buyuklu M, Kandemir FM, Ozkaraca M, Set T, Bakirci EM and Topal E: Protective effect of curcumin against contrast induced nephropathy in rat kidney: what is happening to oxidative stress, inflammation, autophagy and apoptosis? Eur Rev Med Pharmacol Sci 18(4): 461-470, 2014. PMID: 24610611.

50 Peer A, Averbukh Z, Berman S, Modai D, Averbukh M and Weissgarten J: Contrast media augmented apoptosis of cultured renal mesangial, tubular, epithelial, endothelial, and hepatic cells. Invest Radiol 38(3): 177-182, 2003. PMID: 12595799. DOI: $10.1097 / 01 . R L I .0000054529 .61167 .84$

51 Tan X, Zheng X, Huang Z, Lin J, Xie C and Lin Y: Involvement of S100A8/A9-TLR4-NLRP3 inflammasome pathway in contrast-induced acute kidney injury. Cell Physiol Biochem 43(1): 209-222, 2017. PMID: 28854431. DOI: 10.1159/ 000480340

52 Ludwig U, Connemann J and Keller F: Effect of low-osmolar contrast medium iopromide and iso-osmolar iodixanol on DNA fragmentation in renal tubular cell culture. Clin Exp Nephrol 17(6): 779-782, 2013. PMID: 23345070. DOI: 10.1007/s10157013-0774-z

53 Almutairi N, Nour TM and Hussain NH: Janus kinase inhibitors for the treatment of severe alopecia areata: an open-label comparative study. Dermatology 235(2): 130-136, 2019. PMID: 30566941. DOI: $10.1159 / 000494613$

54 Morgan MJ and Thorburn A: Measuring autophagy in the context of cancer. Adv Exp Med Biol 899: 121-143, 2016. PMID: 27325265. DOI: 10.1007/978-3-319-26666-4_8

55 Murugan S and Amaravadi RK: Methods for studying autophagy within the tumor microenvironment. Adv Exp Med Biol 899: 145-166, 2016. PMID: 27325266. DOI: 10.1007/978-3-31926666-4_9 
56 Liang Z, Zhang T, Zhan T, Cheng G, Zhang W, Jia H and Yang $\mathrm{H}$ : Metformin alleviates cisplatin-induced ototoxicity by autophagy induction possibly via the AMPK/FOXO3a pathway. J Neurophysiol 125(4): 1202-1212, 2021. PMID: 33625942. DOI: $10.1152 /$ jn. 00417.2020

$57 \mathrm{He} \mathrm{H,} \mathrm{Xie} \mathrm{H,} \mathrm{Chen} \mathrm{Y,} \mathrm{Li} \mathrm{C,} \mathrm{Han} \mathrm{D,} \mathrm{Xu} \mathrm{F} \mathrm{and} \mathrm{Lyu} \mathrm{J:} \mathrm{Global,}$ regional, and national burdens of bladder cancer in 2017: estimates from the 2017 global burden of disease study. BMC Public Health 20(1): 1693, 2020. PMID: 33176751. DOI: 10.1186/s12889-020-09835-7

58 Cai HK, Chen X, Tang YH and Deng YC: MicroRNA-194 modulates epithelial-mesenchymal transition in human colorectal cancer metastasis. Onco Targets Ther 10: 1269-1278, 2017. PMID: 28280361. DOI: $10.2147 /$ OTT.S125172

59 Persson PB, Hansell P and Liss P: Pathophysiology of contrast medium-induced nephropathy. Kidney Int 68(1): 14-22, 2005. PMID: 15954892. DOI: 10.1111/j.1523-1755.2005.00377.x

60 Blake A, Dragan M, Tirona RG, Hardy DB, Brackstone M, Tuck $\mathrm{AB}$, Babwah AV and Bhattacharya M: G protein-coupled KISS 1 receptor is overexpressed in triple negative breast cancer and promotes drug resistance. Sci Rep 7: 46525, 2017. PMID: 28422142. DOI: $10.1038 /$ srep46525

61 Tasanarong A, Kongkham S and Itharat A: Antioxidant effect of Phyllanthus emblica extract prevents contrast-induced acute kidney injury. BMC Complement Altern Med 14: 138, 2014. PMID: 24755233. DOI: 10.1186/1472-6882-14-138

62 Bajaj P, Reddy B Jr, Millet L, Wei C, Zorlutuna P, Bao G and Bashir R: Patterning the differentiation of $\mathrm{C} 2 \mathrm{C} 12$ skeletal myoblasts. Integr Biol (Camb) 3(9): 897-909, 2011. PMID: 21842084. DOI: $10.1039 / \mathrm{c} 1 \mathrm{ib00058f}$

63 Pinto CF, Watanabe M and Vattimo Mde F: Hydration and Nacetylcysteine in acute renal failure caused by iodinated contrast medium: an experiment with rats. J Nephrol 21(5): 783-788, 2008. PMID: 18949735.
64 Deray G: [Value of $\mathrm{N}$-acetylcysteine to prevent nephrotoxicity from iodinated contrast agents]. J Radiol 85(6 Pt 1): 725-727, 2004. PMID: 15243372. DOI: 10.1016/s0221-0363(04)97674-3

65 Hutcheson IR, Griffith TM, Pitman MR, Towart R, Gregersen $\mathrm{M}$, Refsum $\mathrm{H}$ and Karlsson JO: Iodinated radiographic contrast media inhibit shear stress- and agonist-evoked release of NO by the endothelium. Br J Pharmacol 128(2): 451-457, 1999. PMID: 10510457. DOI: $10.1038 /$ sj.bjp.0702781

66 Boldbaatar K, Dashnyam K, Knowles JC, Lee HH, Lee JH and Kim HW: Dual-ion delivery for synergistic angiogenesis and bactericidal capacity with silica-based microsphere. Acta Biomater 83: 322-333, 2019. PMID: 30465920. DOI: 10.1016/ j.actbio.2018.11.025

67 Jiang W, Li Z, Zhao W, Chen H, Wu Y, Wang Y, Shen Z, He J, Chen S, Zhang J and Fu G: Breviscapine attenuatted contrast medium-induced nephropathy via PKC/Akt/MAPK signalling in diabetic mice. Am J Transl Res 8(2): 329-341, 2016. PMID: 27158329.

68 Andreucci M, Fuiano G, Presta P, Esposito P, Faga T, Bisesti V, Procino A, Altieri V, Tozzo C, Memoli B and Michael A: Radiocontrast media cause dephosphorylation of Akt and downstream signaling targets in human renal proximal tubular cells. Biochem Pharmacol 72(10): 1334-1342, 2006. PMID: 16989777. DOI: $10.1016 /$ j.bcp.2006.08.008
Received July 19, 2021

Revised August 25, 2021

Accepted August 26, 2021 